\title{
Palaeobiology, ecology, and distribution of stromatoporoid faunas in biostromes of the mid-Ludlow of Gotland, Sweden
}

Olof Sandström and Steve Kershaw

Acta Palaeontologica Polonica 53 (2), 2008: 293-302 doi:http://dx.doi.org/10.4202/app.2008.0210

Six well exposed mid-Ludlow stromatoporoid-dominated reef biostromes in four localities from the Hemse Group in southeastern Gotland, Sweden comprise a stromatoporoid assemblage dominated by four species; Clathrodictyon mohicanum, "Stromatopora" bekkeri, Plectostroma scaniense, and Lophiostroma schmidtii. All biostromes investigated in this area (of approximately $30 \mathrm{~km} 2$ ) are interpreted to belong to a single faunal assemblage forming a dense accumulation of fossils that is probably the best exposed stromatoporoid-rich deposit of the Silurian. The results from this comprehensive study strengthen earlier interpretations of a combination of genetic and environmental control on growth-forms of the stromatoporoids. Growth styles are similar for stromatoporoids in all six biostromes. Differences in biostrome fabric are due to variations in the degree of disturbance by storms. The uniformity of facies and the widespread low-diversity fauna support the view that palaeoenvironmental conditions were similar across the area where these biostromes crop out, and promoted the extraordinary growth of stromatoporoids in this shallow shelf area.

Key words: Stromatoporoids, palaeoecology, depositional environment, morphotype, Silurian, Gotland, Sweden

Olof Sandström [olof.sandstrom@smamineral.com], SMA Mineral AB, Kapellgatan 10, SE-214 21 Malmö, Sweden; Steve Kershaw [stephen.kershaw @brunel.ac.uk], Institute for the Environment, Brunel University, Uxbridge UB8 3PH, United Kingdom.

This is an open-access article distributed under the terms of the Creative Commons Attribution License (for details please see creativecommons.org), which permits unrestricted use, distribution, and reproduction in any medium, provided the original author and source are credited. 
FaF Full text $(499.5 \mathrm{kB})$ 